\title{
Badanie wpływu charakteru olejów bazowych na właściwości smarów bentonitowych
}

Praca dotyczy badania wpływu olejów bazowych o różnym charakterze na właściwości wytworzonych smarów bentonitowych. Próbki smarów zostały sporządzone w oparciu o różne bazy olejowe o charakterze parafinowym i naftenowym, a także różnorodne typy zagęszczaczy na bazie modyfikowanego bentonitu. Scharakteryzowano smary bentonitowe, opisano technologię ich wytwarzania i zastosowania. Oznaczono właściwości wytworzonych smarów plastycznych.

Słowa kluczowe: smary bentonitowe, oleje bazowe, właściwości.

\section{Study on the influence of the character of base oils on the properties of bentonite greases}

The purpose of the thesis was to examine the impact of base oils of a different character on the properties of produced bentonite greases. Samples of greases were prepared based on different base oils of paraffin and naphthenic character and different types of thickeners based on modified bentonite. The work discusses characterization of bentonite grease, technology of their production and application. The properties of produced bentonite greases were tested.

Key words: bentonite greases, base oils, properties.

\section{Wprowadzenie}

Rozwój przemysłu wymusza na jednostkach naukowo-badawczych oraz na producentach smarów opracowanie nowoczesnych technologii produkcji smarów, opartych na wysokojakościowych bazach olejowych oraz dodatkach uszlachetniających. Oleje bazowe w smarach

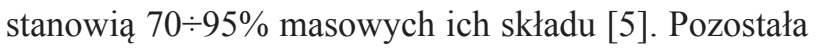
część to zagęszczacz i dodatki uszlachetniające, które służą do poprawy właściwości eksploatacyjnych smaru.

Smary plastyczne w zależności od rodzaju zagęszczacza charakteryzują się różnorodnymi właściwościami. Zagęszczacz, stanowiący około $7 \div 25 \%(\mathrm{~m} / \mathrm{m})$, w istotny sposób wpływa na parametry eksploatacyjne smaru plastycznego. W zależności od rodzaju zagęszczacza smary dzieli się na: mydlane (z mydłami prostymi i kompleksowymi), zawierające zagęszczacze mieszane, węglowodorowe, z zagęszczaczami nieorganicznymi oraz smary z zagęszczaczami polimerowymi [2]. Smary bentonitowe stanowią niewielki udział w światowej produkcji smarów - około $2 \%(\mathrm{~m} / \mathrm{m})$. Na rysunku 1 przedstawiono procentowy udział poszczególnych typów smarów plastycznych w produkcji światowej.

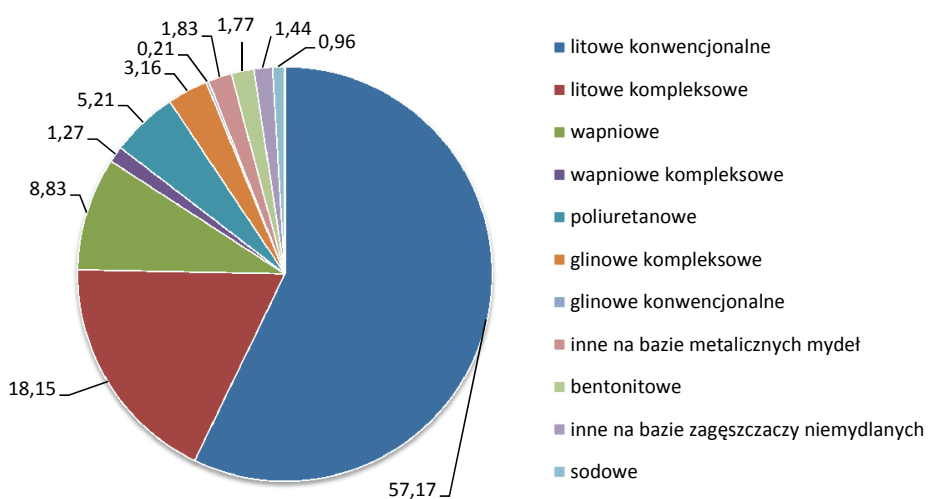

Rys. 1. Udział poszczególnych smarów plastycznych w produkcji światowej w \% $(\mathrm{m} / \mathrm{m})[4]$

Poszczególne smary różnią się między sobą nie tylko zawartością konkretnych zagęszczaczy, ale również właściwościami fizykochemicznymi oraz konsystencją. Podstawę $\mathrm{w}$ wyborze smaru stanowi zatem wiedza na temat urządzenia, warunków, w jakich będzie ono pracować, a także ograniczeń oraz zalet poszczególnych rodzajów smarów. 
Coroczne kongresy Europejskiego Instytutu Smarowego (ELGI - European Lubricating Grease Institute) wyznaczają nie tylko kierunki rozwoju produktów - smarów, ale także ujednolicają standardy i wspierają wymianę doświadczeń pomiędzy firmami [5]. Prowadzone są nieustanne prace nad nowymi technologiami, szczególnie nad wy- sokojakościowymi kompleksowymi smarami pozwalającymi na pracę w ekstremalnych warunkach [3]. Z uwagi na dobrą odporność na wysokie i niskie temperatury czy odporność na wodę, za takie uważane są smary bentonitowe - produkty wielofunkcyjne stosowane $\mathrm{w}$ wielu węzłach tribologicznych.

\section{Właściwości i zastosowanie smarów bentonitowych}

Smary bentonitowe, określane jako smary specjalne, powstają poprzez zagęszczenie olejów bazowych o dużej lepkości warstwowymi glinokrzemianami, np. modyfikowanym bentonitem.

Skład chemiczny smarów bentonitowych oraz odpowiedni sposób ich wytwarzania pozwalają na uzyskanie środka smarowego o specyficznych właściwościach. Smary te charakteryzują się przede wszystkim wysoką trwałością podczas pracy, zarówno w wysokich, jak i niskich temperaturach, a także odpornością na znaczne wahania temperatury. Brak twardnienia smaru wraz ze spadkiem temperatury oraz nieznaczne mięknienie smaru przy wzroście temperatury pozwalają na szeroki zakres warunków jego eksploatacji. Dodatkowo do zalet smarów bentonitowych należy odporność na działanie wody, spowodowana słabą rozpuszczalnością glinki bentonitowej.

Do wad smarów bentonitowych można zaliczyć brak ich mieszalności z innymi smarami, dużą ilość dodatków polarnych, a także słabą wytrzymałość na ścinanie mechaniczne [9]. Pomimo swoich wad smary te znajdują zastosowanie w wielu ważnych węzłach tribologicznych [2]:

- łożyskach, które w trakcie eksploatacji poddane są działaniu wody o wysokiej temperaturze; łożyska te są wykorzystywane np. w pompach służących do transportu gorącej wody,

- łożyskach, które w trakcie eksploatacji poddane są działaniu wysokiej temperatury, między innymi w przemyśle gumowym, stalowym czy przeróbki szkła,

- łożyskach urządzeń, które wykorzystuje się do mieszania gorących produktów.

W tablicy 1 przedstawiono przykładowe smary bentonitowe wyprodukowane w kraju przez producentów: Orlen Oil, PDP Naftochem, Lotos Oil, a także zebrano ich właściwości fizykochemiczne.

Tablica 1. Przykładowe smary bentonitowe wyprodukowane w kraju oraz ich właściwości fizykochemiczne [11, 12, 13]

\begin{tabular}{|c|c|c|c|c|c|}
\hline \multirow{2}{*}{ Właściwości } & \multirow{2}{*}{ Jednostka } & \multicolumn{3}{|c|}{ Smar } & \multirow{2}{*}{ Metody badań } \\
\hline & & Bentor 2 & Benterm 2 & Bentor 2 & \\
\hline Producent & - & Orlen Oil & PDP Naftochem & Lotos Oil & - \\
\hline $\begin{array}{l}\text { Penetracja w temperaturze } 25^{\circ} \mathrm{C} \text { po } 60 \text { cyklach } \\
\text { ugniatania }\end{array}$ & {$[\mathrm{mm} / 10]$} & 295 & $260 \div 300$ & $260 \div 300$ & ASTM D 217 \\
\hline Klasa konsystencji wg NLGI & - & 2 & 2 & 2 & PN-C-04095 \\
\hline Temperatura kroplenia (minimum) & {$\left[{ }^{\circ} \mathrm{C}\right]$} & brak & 220 & brak & ASTM D 2265 \\
\hline $\begin{array}{l}\text { Wydzielanie oleju w temperaturze } 150^{\circ} \mathrm{C} \mathrm{w} \text { czasie } \\
24 \text { godz. (maksimum) }\end{array}$ & {$[\%(m / m)]$} & - & 5 & - & BN-0536-11 \\
\hline $\begin{array}{l}\text { Badanie działania korodującego na płytkach mie- } \\
\text { dzianych w temperaturze } 100^{\circ} \mathrm{C} \text { w czasie } 3 \text { godz. }\end{array}$ & - & - & wytrzymuje & - & PN-C-04093 \\
\hline $\begin{array}{l}\text { Odporność na działanie wody w temperaturze } \\
\text { wrzenia (minimum) }\end{array}$ & {$[\mathrm{min}]$} & - & 30 & - & PN-C-96013 \\
\hline Wydzielanie oleju ze smaru & {$[\%(m / m)]$} & 8,0 & - & 8,0 & PN-C-04136 \\
\hline $\begin{array}{l}\text { Mikropenetracja po } 4 \text { godz. wałkowania w tempe- } \\
\text { raturze } 60^{\circ} \mathrm{C}\end{array}$ & {$[\mathrm{mm} / 10]$} & 172 & - & 170 & PN-C-04144 \\
\hline $\begin{array}{l}\text { Lepkość kinematyczna oleju bazowego w tempe- } \\
\text { raturze } 40^{\circ} \mathrm{C}\end{array}$ & {$\left[\mathrm{mm}^{2} / \mathrm{s}\right]$} & - & - & 500 & ASTM D 445 \\
\hline
\end{tabular}




\section{Metodyka badań}

W pracy wykorzystano następujące metody badań smarów plastycznych:

- pomiar penetracji smarów plastycznych w temperaturze $25^{\circ} \mathrm{C}$, według normy PN-ISO 2137:2011 [25], polega na wyznaczeniu liczby penetracji. Liczba ta jest podstawą podziału smarów plastycznych na klasy konsystencji NLGI (National Lubricating Greases Institute). Zasada pomiaru polega na zmierzeniu stopienia wniknięcia w smar standardowego stożka, o znormalizowanym kształcie i znanej masie, w czasie 5 sekund, w temperaturze $25^{\circ} \mathrm{C}$. W pracy oznaczano penetrację smaru po ugniataniu - po uprzednim mechanicznym ugniataniu smaru w naczyniu penetracyjnym, tzn. po wykonaniu 60 podwójnych suwów tłoka. Podczas oceny smarów do badań wykorzystywano stożek w skali, a wynik pomiaru przeliczono na penetrację w skali 1:1;

- pomiar penetracji smaru po ugniataniu - na jego podstawie określano klasę konsystencji smaru, według PN-C04095:1985 [23]. Klasyfikacja ta wyróżnia 10 klas konsystencji smarów plastycznych - w zależności od liczby penetracji. Smary posiadające niską klasę konsystencji są określane jako półpłynne, zaś wysokie wartości klas charakteryzują smary twarde;
- oznaczanie stabilności mechanicznej smarów stałych, według normy PN-C-04144:1962 [24], przeprowadza się w celu określenia zmiany w strukturze smaru spowodowanej działaniem sił ścinających powstających podczas wałkowania smaru w aparacie roll-test $\mathrm{w}$ temperaturze $60^{\circ} \mathrm{C}$, w czasie 4 godzin. Stabilność mechaniczną określa się poprzez zmianę penetracji smaru po wałkowaniu. Wynik stabilności mechanicznej smaru określano w procentach jako zmianę penetracji smaru po wałkowaniu w stosunku do smaru niewałkowanego;

- badanie skłonności do wydzielenia się oleju ze smaru, według normy PN-V-04047:2002 [26], ocenia ilość wydzielonego oleju ze smaru, co za tym idzie - określa stabilność układu zagęszczacz-olej oraz predyspozycję smaru do wydzielenia oleju na skutek przechowywania lub pod wpływem temperatury. Zasada pomiaru polega na tym, że zważoną próbkę smaru umieszcza się w stożku wykonanym z siatki niklowej, a następnie przechowuje się w wysokiej temperaturze przez określony czas. W pracy zastosowano następujące warunki: czas badania - 30 godzin, temperatura $-100^{\circ} \mathrm{C}$. Wyniki pomiarów podano jako procent wagowy wydzielonego oleju.

\section{Surowce}

\section{Oleje bazowe}

Podstawą doboru składników do produkcji smarów oprócz wiedzy na temat urządzenia oraz warunków, w jakich dany smar będzie pracować, jest wybór bazy olejowej o odpowiednich właściwościach fizykochemicznych, dobór ilości i rodzaju zagęszczacza oraz dodatków uszlachetniających.

Olej jako podstawowy składnik smaru bentonitowego decyduje o jego właściwościach użytkowych. Cechami, które charakteryzują przydatność oleju bazowego do produkcji danego rodzaju smaru, są między innymi: lepkość, charakterystyka lepkościowo-temperaturowa, właściwości niskotemperaturowe, smarne oraz odporność na utlenianie.

Do produkcji smarów bentonitowych wykorzystuje się wysokolepkie oleje, tj. o lepkości wynoszącej od 300 do $1100 \mathrm{~mm}^{2} / \mathrm{s}$ w temperaturze $40^{\circ} \mathrm{C}$. Przydatność olejów do produkcji smarów bentonitowych należy rozpatrywać z uwzględnieniem zastosowanego zagęszczacza nieorganicznego, jego wpływu na stopień zagęszczania oleju bazowego, a także na własności użytkowe gotowego smaru [2].

Do produkcji smarów bentonitowych wytypowano oleje bazowe:

- olej o charakterze parafinowym: I GRUPA według API - olej BS 30/90 produkcji Lotos Oil,
- olej o charakterze naftenowym: V GRUPA według API - olej T 400 produkcji firmy Nynas.

Charakterystyka wykorzystanych baz olejowych przedstawia się następująco:

- olej bazowy BS 30/90 - otrzymany z ropy parafinowej - zalicza się do I grupy olejów klasyfikowanych według API. Jest to olej pozostałościowy typu brightstock. Otrzymuje się go w wyniku zachowawczej przeróbki pozostałości próżniowej ropy naftowej, w procesach odasfaltowania propanem, selektywnej rafinacji furfurolem, odparafinowania metodą rozpuszczalnikową i ostatecznie poprzez rafinację wodorem. W temperaturze pokojowej jest klarowną cieczą o bursztynowym kolorze i charakterystycznym olejowym zapachu. Nie posiada właściwości wybuchowych, nie rozpuszcza się w wodzie, za to rozpuszcza się w większości rozpuszczalników organicznych. Posiada bardzo słabą lotność. Olej charakteryzuje się lepkością kinematyczną w temperaturze $40^{\circ} \mathrm{C}$ na poziomie $450 \div 600 \mathrm{~mm}^{2} / \mathrm{s}$ [7];

- olej bazowy T 400 - jest przedstawicielem olejów o charakterze naftenowym, zaliczanym do $\mathrm{V}$ grupy według klasyfikacji API. W temperaturze pokojowej jest to jasnożółta, klarowna, przeważnie bezzapachowa ciecz. 
Tablica 2. Właściwości wytypowanych baz olejowych, na podstawie specyfikacji producentów [7, 8]

\begin{tabular}{|c|c|c|c|c|}
\hline \multirow{2}{*}{ Właściwości } & \multirow{2}{*}{ Jednostka } & \multicolumn{2}{|c|}{ Nazwa oleju } & \multirow{2}{*}{ Metoda badań } \\
\hline & & BS 30/90 & T 400 & \\
\hline Charakter bazy & - & parafinowa & naftenowa & - \\
\hline Klasyfikacja według API & numer grupy & I & $\mathrm{V}$ & - \\
\hline $\begin{array}{l}\text { Zawartość [\%]: } \\
-\mathrm{C}_{\text {parafin }} \\
-\mathrm{C}_{\text {naftenów }} \\
-\mathrm{C}_{\text {aromatów }}\end{array}$ & $\begin{array}{l}- \\
- \\
-\end{array}$ & $\begin{array}{l}- \\
- \\
-\end{array}$ & $\begin{array}{l}55 \\
33 \\
12\end{array}$ & ASTM D 2140 \\
\hline Gęstość w temperaturze $15^{\circ} \mathrm{C}$ & {$\left[\mathrm{kg} / \mathrm{dm}^{3}\right]$} & 0,906 & 0,922 & PN-EN ISO 12185 \\
\hline Lepkość kinematyczna $\mathrm{w} 40^{\circ} \mathrm{C}$ & {$\left[\mathrm{mm}^{2} / \mathrm{s}\right]$} & 591 & 372 & PN-EN ISO 3104 \\
\hline Lepkość kinematyczna $\mathrm{w} 100^{\circ} \mathrm{C}$ & {$\left[\mathrm{mm}^{2} / \mathrm{s}\right]$} & 34,5 & 18 & PN-EN ISO 3104 \\
\hline Wskaźnik lepkości (minimum) & - & 91 & niski & ASTM D 2270 \\
\hline Punkt anilinowy & {$\left[{ }^{\circ} \mathrm{C}\right]$} & - & 98 & ASTM D 611 \\
\hline Temperatura zapłonu (minimum) & {$\left[{ }^{\circ} \mathrm{C}\right]$} & 322 & 264 & PN-EN ISO 2592 \\
\hline Temperatura płynięcia (maksimum) & {$\left[{ }^{\circ} \mathrm{C}\right]$} & -9 & -18 & ASTM D 97 \\
\hline Liczba kwasowa (maksimum) & {$[\mathrm{mg} \mathrm{KOH} / \mathrm{g}]$} & 0,02 & 0,03 & ASTM D 974 \\
\hline Zawartość siarki & {$[\%]$} & - & 0,12 & ASTM D 2622 \\
\hline
\end{tabular}

Posiada niski wskaźnik lepkości oraz bardzo dobre właściwości niskotemperaturowe. Olej charakteryzuje się lepkością kinematyczną w temperaturze $40^{\circ} \mathrm{C}$ na poziomie $360 \div 420 \mathrm{~mm}^{2} / \mathrm{s}$. Podobnie jak wszystkie oleje jest on nierozpuszczalny w wodzie, rozpuszczalny zaś w rozpuszczalnikach organicznych [8].

W tablicy 2 przedstawiono podstawowe właściwości zastosowanych olejów bazowych.

Przebadano podstawowe parametry fizykochemiczne zastosowanych olejów bazowych:

- olej BS 30/90 charakteryzował się lepkością kinematyczną w temperaturze $40^{\circ} \mathrm{C}$ o wartości $526,2 \mathrm{~mm}^{2} / \mathrm{s}$, temperaturą zapłonu $\mathrm{w}$ tyglu otwartym $321^{\circ} \mathrm{C}$ i temperaturą płynięcia $-9^{\circ} \mathrm{C}$,
- olej T 400 wyróżniał się lepkością kinematyczną w temperaturze $40^{\circ} \mathrm{C}$ o wartości $394,5 \mathrm{~mm}^{2} / \mathrm{s}$, temperaturą zapłonu w tyglu otwartym $267^{\circ} \mathrm{C}$ i temperaturą płynięcia $-21^{\circ} \mathrm{C}$.

\section{Zagęszczacze}

Do wytworzenia próbek smarów wytypowano zagęszczacze:

- Baragel 3000 - produkcji firmy Elementis Specialties, Inc.,

- Pangel B5, Pangel OM4, Pangel B20, Pangel OMD1 produkcji firmy Tolsa Group,

- Viscogel SD, Viscogel XDE, Viscogel S4 - produkcji firmy Laviosa Minerals Italia.

Na podstawie zebranych informacji od producentów zagęszczaczy bentonitowych sporządzono tablicę 3 uwzględniającą krótki opis i zastosowanie danego zagęszczacza.

Tablica 3. Charakterystyka zastosowanych zagęszczaczy bentonitowych [15-19, 21]

\begin{tabular}{|c|c|c|}
\hline $\begin{array}{l}\text { Nazwa } \\
\text { i producent }\end{array}$ & Właściwości & Charakterystyka \\
\hline $\begin{array}{c}\text { Baragel } \\
\text { Elementis } \\
\text { Specialties, } \\
\text { Inc. }\end{array}$ & $\begin{array}{l}\text { - proszek o jasnej barwie } \\
\text { - nie wymaga aktywacji za pomo- } \\
\text { cą chemicznego aktywatora } \\
\text { - łatwa dyspersja w oleju } \\
\text { - mała wrażliwość na ścinanie } \\
\text { - wysoce wydajny } \\
\text { - zapewnia doskonałą trwałość } \\
\text { mechaniczną }\end{array}$ & $\begin{array}{l}\text { Baragel 3000: } \\
\text { - organicznie modyfikowana glina bentonitowa } \\
\text { - do zagęszczenia smarów na bazie olejów mineralnych oraz olejów syntetycz- } \\
\text { nych o średnich-wysokich wskaźnikach lepkości } \\
\text { - wymaga promotora dyspersji - wody w ilości } 0,1 \% \text { wag. } \\
\text { - dodatek } 2 \% \text { acetonu powoduje wzrost penetracji po ugniataniu } \\
\text { - zalecany poziom dozowania } 6 \text { do } 15 \%\end{array}$ \\
\hline
\end{tabular}


cd. Tablica 2

\begin{tabular}{|c|c|c|}
\hline $\begin{array}{l}\text { Nazwa } \\
\text { i producent }\end{array}$ & Właściwości & Charakterystyka \\
\hline $\begin{array}{l}\text { Pangel } \\
\text { TOLSA } \\
\text { GROUP }\end{array}$ & $\begin{array}{l}\text { - proszek o jasnej barwie } \\
\text { - brak konieczności zastosowania } \\
\quad \text { polarnego aktywatora } \\
\text { - wysoka zdolność zagęszczania } \\
\text { - prosty proces dyspersji } \\
\text { - dobra stabilność } \\
\text { - zmniejszony proces sedymentacji }\end{array}$ & $\begin{array}{l}\text { Pangel B5: } \\
\text { - do niskopolarnych układów: rozpuszczalników alifatycznych, olejów mine- } \\
\text { ralnych, olejów syntetycznych } \\
\text { Pangel OM4: } \\
\text { - na bazie wysokooczyszczonej glinki bentonitowej } \\
\text { - do niskopolarnych układów: rozpuszczalników alifatycznych, mineralnych, } \\
\text { olejów syntetycznych } \\
\text { Pangel B20: } \\
\text { - na bazie sepiolitu - uwodornionego krzemianu magnezu modyfikowanego } \\
\text { IV rz. solami amoniowymi - i krystalicznej krzemionki } \\
\text { - do średniopolarnych układów: olejów naftenowych, olejów aromatycznych, } \\
\text { olejów roślinnych } \\
\text { Pangel OMD1: } \\
\text { - na bazie wysokiej czystości glinki bentonitowej } \\
\text { - do średniopolarnych układów: rozpuszczalników alifatycznych, olejów mine- } \\
\text { ralnych, olejów syntetycznych }\end{array}$ \\
\hline $\begin{array}{c}\text { Viscogel } \\
\text { Laviosa } \\
\text { Minerals } \\
\text { Italia }\end{array}$ & $\begin{array}{l}\text { - proszek o jasnej barwie } \\
\text { - brak konieczności zastosowania } \\
\quad \text { polarnego aktywatora }\end{array}$ & $\begin{array}{l}\text { Viscogel SD: } \\
\text { - na bazie wysokiej czystości glinki bentonitowej - smektytu modyfikowanego } \\
\text { IV rz. solami alkiloamoniowymi } \\
\text { - łatwy w dyspersji, nie wymaga silnego mieszania, } \\
\text { - do mineralnych alkoholi alifatycznych, węglowodorów aromatycznych } \\
\text { Viscogel XDE: } \\
\text { - na bazie glinki smektytu modyfikowanej IV rz. solami alkiloamoniowymi } \\
\text { - do olejów mineralnych } \\
\text { Viscogel S4: } \\
\text { - na bazie glinki bentonitowej modyfikowanej IV rz. solami alkiloamoniowymi } \\
\text { - do stosowania w rozpuszczalnikach alifatycznych i olejach mineralnych }\end{array}$ \\
\hline
\end{tabular}

\section{Proces wytwarzania smarów bentonitowych}

Sporządzono próbki smarów zawierające 8\% i 10\% zagęszczacza, zarówno na bazie oleju BS 30/90, jak i T 400. Przy wykorzystaniu zagęszczacza Baragel 3000 jako aktywator zastosowano wodę w stężeniu $0,1 \%(\mathrm{~m} / \mathrm{m})$ oraz aceton w stężeniu $3 \%(\mathrm{~m} / \mathrm{m})$ (zgodnie z zaleceniem producenta). W przypadku pozostałych zagęszczaczy jako aktywator wykorzystano wodę w stężeniu $0,1 \%(\mathrm{~m} / \mathrm{m})$.

Próbki zostały sporządzone na postawie dwóch receptur:

\section{- I receptura - stosowana dla smarów aktywowanych}

\section{acetonem}

Próbki wytwarzano w zlewce szklanej o pojemności $250 \mathrm{ml}$.

Do $1 / 3$ objętości oleju dodano $8 \%(\mathrm{~m} / \mathrm{m})$ zagęszczacza. Stosując mieszadło mechaniczne, mieszano w temperaturze pokojowej przez 30 minut, przy prędkości 2000 obr/min. Następnie dozowano 3\% $(\mathrm{m} / \mathrm{m})$ acetonu i całość mieszano przez 15 minut. Później do całości dodano pozostałą ilość oleju i kontynuowano mieszanie przez 30 minut.

\section{- II receptura - stosowana dla smarów aktywowa- nych wodą}

Próbki wytwarzano w zlewce szklanej o pojemności $250 \mathrm{ml}$. Do całości oleju dodano odpowiednio $8 \%(\mathrm{~m} / \mathrm{m})$ lub $10 \%(\mathrm{~m} / \mathrm{m})$ zagęszczacza. Stosując mieszadło mechaniczne, mieszano w temperaturze pokojowej przez 10 minut, przy prędkości 800 obr/min. Następnie dozowano $0,1 \%(\mathrm{~m} / \mathrm{m})$ wody i całość mieszano przez 30 minut. Wytworzone próbki poddano procesowi homogenizacji w młynie korundowym typu fryma, przy szczelinie $0,2 \mathrm{~mm}$. Dla części próbek nie uzyskano produktu o konsystencji smaru. Pozostałe próbki smarów zostały poddane podstawowym badaniom parametrów fizykochemicznych: penetracji po ugniataniu (60 razy), temperatury kroplenia, stabilności mechanicznej i skłonności do wydzielania oleju.

W tablicy 4 zestawiono skład i właściwości wyprodukowanych smarów bentonitowych. 
Tablica 4. Skład i właściwości wyprodukowanych smarów bentonitowych

\begin{tabular}{|c|c|c|c|c|c|c|c|}
\hline $\begin{array}{c}\text { Typ } \\
\text { zagęszczacza }\end{array}$ & $\begin{array}{c}\text { Olej } \\
\text { bazowy }\end{array}$ & $\begin{array}{l}\text { Aktywator } \\
\text { (promotor } \\
\text { dyspersji) }\end{array}$ & $\begin{array}{c}\text { Udział zagęszcza- } \\
\text { cza/oleju bazowe- } \\
\text { go/aktywatora } \\
{[\%(\mathrm{~m} / \mathrm{m})]}\end{array}$ & $\begin{array}{l}\text { Wartość } \\
\text { penetracji } \\
{[\mathrm{mm} / 10]}\end{array}$ & $\begin{array}{c}\text { Klasa } \\
\text { konsystencji }\end{array}$ & $\begin{array}{c}\text { Stabilność mecha- } \\
\text { niczna po } 4 \text { godz. } \\
\text { w temperaturze } \\
100^{\circ} \mathrm{C} \\
{[\%]}\end{array}$ & $\begin{array}{c}\text { Wydzielenie oleju } \\
\text { ze smaru w tempe- } \\
\text { raturze } 100^{\circ} \mathrm{C} \text {, } \\
\text { w czasie } 30 \text { godz. } \\
{[\%(\mathrm{~m} / \mathrm{m})]}\end{array}$ \\
\hline Baragel 3000 & BS $30 / 90$ & aceton & $8,00 / 89,0 / 3,00$ & 242 & 3 & 71,73 & 0,00 \\
\hline Baragel 3000 & BS 30/90 & woda & $8,00 / 91,90 / 0,10$ & 215 & 3 & 84,10 & 0,00 \\
\hline Baragel 3000 & T 400 & woda & $8,00 / 91,90 / 0,10$ & 268 & 2 & 67,21 & 0,04 \\
\hline Baragel 3000 & T 400 & aceton & $8,00 / 89,0 / 3,00$ & 279 & 2 & 51,61 & 0,00 \\
\hline Pangel B5 & BS 30/90 & woda & $8,00 / 91,90 / 0,10$ & 260 & 2 & 51,52 & 0,81 \\
\hline Pangel B5 & Т 400 & woda & $8,00 / 91,90 / 0,10$ & 377 & 0 & 20,00 & 2,16 \\
\hline Pangel OM4 & BS 30/90 & woda & $8,00 / 91,90 / 0,10$ & \multirow{2}{*}{\multicolumn{4}{|c|}{ próbka odrzucona z powodu braku uzyskania konsystencji smaru }} \\
\hline Pangel OM4 & T 400 & woda & $8,00 / 91,90 / 0,10$ & & & & \\
\hline Pangel B20 & BS 30/90 & woda & $8,00 / 91,90 / 0,10$ & 287 & 2 & 57,58 & 1,64 \\
\hline Pangel B20 & T 400 & woda & $8,00 / 91,90 / 0,10$ & 317 & 1 & 39,51 & 2,28 \\
\hline Pangel OMD1 & BS 30/90 & woda & $8,00 / 91,90 / 0,10$ & \multirow{2}{*}{\multicolumn{4}{|c|}{ próbka odrzucona z powodu braku uzyskania konsystencji smaru }} \\
\hline Pangel OMD1 & $\mathrm{T} 400$ & woda & $8,00 / 91,90 / 0,10$ & & & & \\
\hline Viscogel SD & BS 30/90 & woda & $8,00 / 91,90 / 0,10$ & 275 & 2 & 36,51 & 1,59 \\
\hline Viscogel SD & T 400 & woda & $8,00 / 91,90 / 0,10$ & 365 & 0 & 22,10 & 4,51 \\
\hline Viscogel XDE & BS 30/90 & woda & $8,00 / 91,90 / 0,10$ & 215 & 3 & 58,50 & 1,41 \\
\hline Viscogel XDE & T 400 & woda & $8,00 / 91,90 / 0,10$ & 305 & 1 & 55,07 & 3,01 \\
\hline Viscogel S4 & BS 30/90 & woda & $8,00 / 91,90 / 0,10$ & \multirow{2}{*}{\multicolumn{4}{|c|}{ próbka odrzucona z powodu braku uzyskania konsystencji smaru }} \\
\hline Viscogel S4 & T 400 & woda & $8,00 / 91,90 / 0,10$ & & & & \\
\hline Baragel 3000 & BS 30/90 & woda & $10,00 / 89,90 / 0,10$ & 212 & 4 & 59,52 & 0,09 \\
\hline Baragel 3000 & T 400 & woda & $10,00 / 89,90 / 0,10$ & 257 & 3 & 27,27 & 0,44 \\
\hline Viscogel XDE & BS 30/90 & woda & $10,00 / 89,90 / 0,10$ & 193 & 4 & 104,88 & 0,06 \\
\hline Viscogel XDE & T 400 & woda & $10,00 / 89,90 / 0,10$ & 260 & 2 & 70,18 & 0,35 \\
\hline
\end{tabular}

\section{Omówienie wyników badań}

\section{Badanie wptywu rodzaju bazy olejowej i zagęszczacza na konsystencję smaru}

Dla uzyskanych próbek smarów wykonano oznaczenie średniej penetracji po 60 cyklach ugniatania. Wyznaczoną wartość penetracji dla poszczególnych próbek przedstawiono na rysunku 2.

Próbki smarów wytworzone z udziałem oleju BS 30/90 charakteryzowały się niższą penetracją po ugniataniu niż analogiczne próbki powstałe na bazie oleju T 400. Największą różnicę w przypadku zagęszczania olejów o różnym charakterze chemicznym zaobserwowano dla zagęszczacza Pangel B5 (powyżej 100 jednostek), natomiast najmniejszą dla zagęszczacza Pangel B20 (poniżej 40 jednostek).

Konsystencja wytworzonych smarów, oprócz charakteru stosowanego oleju, była również zależna od rodzaju użytego zagęszczacza. Najtwardszą konsystencję posiadały smary wyprodukowane $\mathrm{z}$ wykorzysta- niem zagęszczacza Baragel 3000. Ponadto zaobserwowano, że w przypadku tego zagęszczacza użycie wody jako aktywatora przyczyniało się do uzyskania twardszej konsystencji smaru. W przypadku próbek z zastosowaniem zagęszczacza

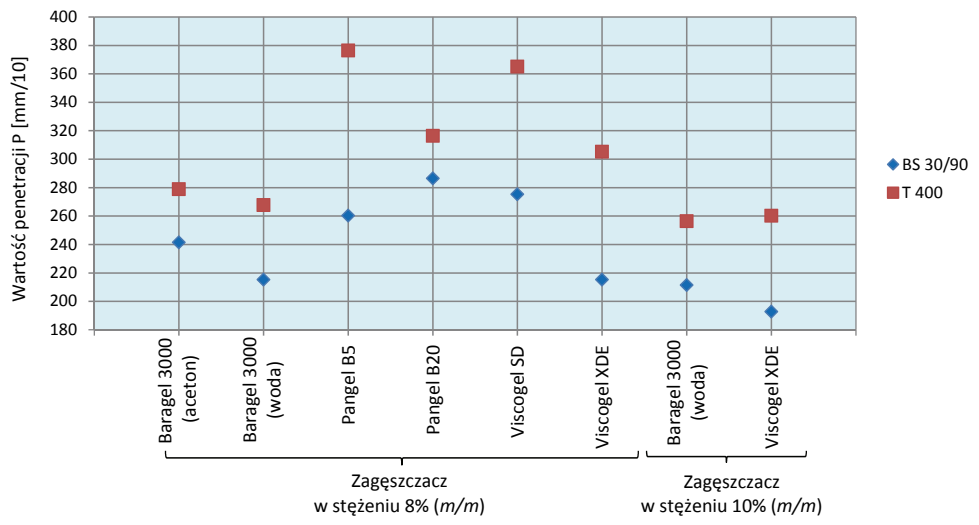

Rys. 2. Wpływ zagęszczacza na konsystencję wytworzonych próbek smarów bentonitowych 
Baragel 3000 i Viscogel XSD, aktywowanych wodą, zaobserwowano, że wzrost stężenia zagęszczacza w smarze po- wodował nieznaczny spadek wartości penetracji wyprodukowanego smaru.

\section{Oznaczenie stabilności mechanicznej uzyskanych próbek smarów}

Dla uzyskanych próbek smarów wykonano oznaczenie stabilności mechanicznej. Wyniki tych pomiarów przedstawiono na rysunku 3. Otrzymane wyniki wykazują, że wszystkie wyprodukowane smary cechowały się słabą stabilnością mechaniczną.

Spośród przebadanych próbek smar wytworzony na bazie oleju T 400, z wykorzystaniem Pangelu B5 jako zagęszczacza, charakteryzował się najlepszą stabilnością mechaniczną (tylko 20\%). Natomiast smar wyprodukowany na bazie oleju BS 30/90, z wykorzystaniem Viscogelu XDE jako zagęszczacza, odznaczał się najgorszą stabilnością mechaniczną (powyżej 100\%). Zaobserwowano, że smary wytworzone na bazie parafinowej charakteryzowały się gorszą stabilnością mechaniczną niż analogiczne smary wyprodukowane na bazie naftenowej. Nie odnotowano charaktery-

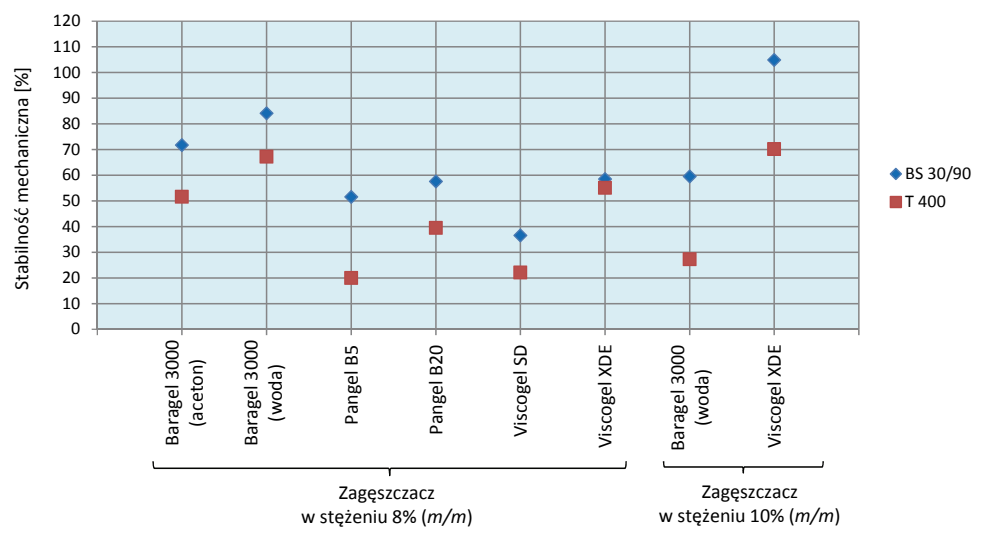

Rys. 3. Wpływ zagęszczacza na stabilność mechaniczną wytworzonych próbek smarów bentonitowych

stycznej zależności wpływu ilości zagęszczacza na zmianę wartości stabilności mechanicznej.

\section{Oznaczenie skłonności do wydzielenia oleju ze smaru}

Wszystkie wytworzone próbki smarów charakteryzowały się niewielką skłonnością do wydzielania oleju w wysokiej temperaturze - ilość wydzielonego oleju nie przekraczała $5 \%(\mathrm{~m} / \mathrm{m})$. Próbki powstałe na bazie oleju BS 30/90 posiadały mniejszą tendencję do zjawiska synerezy, czyli do skłonności wydzielania oleju, niż smary wyprodukowane na bazie oleju T 400. Smar wytworzony przy udziale zagęszczacza Baragel 3000 charakteryzował się najmniejszą skłonnością do wydzielania oleju $(0 \%)$ - w warunkach badania nie zaobserwowano wydzielenia oleju ze smaru. Smar wyprodukowany na bazie oleju T 400, zagęszczony Viscogelem SD, odznaczał się największą skłonnością do wydzielania oleju, na poziomie $4,5 \%$. W przypadku smarów wytworzonych z udziałem Baragelu 3000 skuteczniejszym promotorem dyspersji niż woda okazał się aceton - tak powstały smar charakteryzował się mniejszą skłonnością do wydzielania oleju. Nie można jednoznacznie określić za-

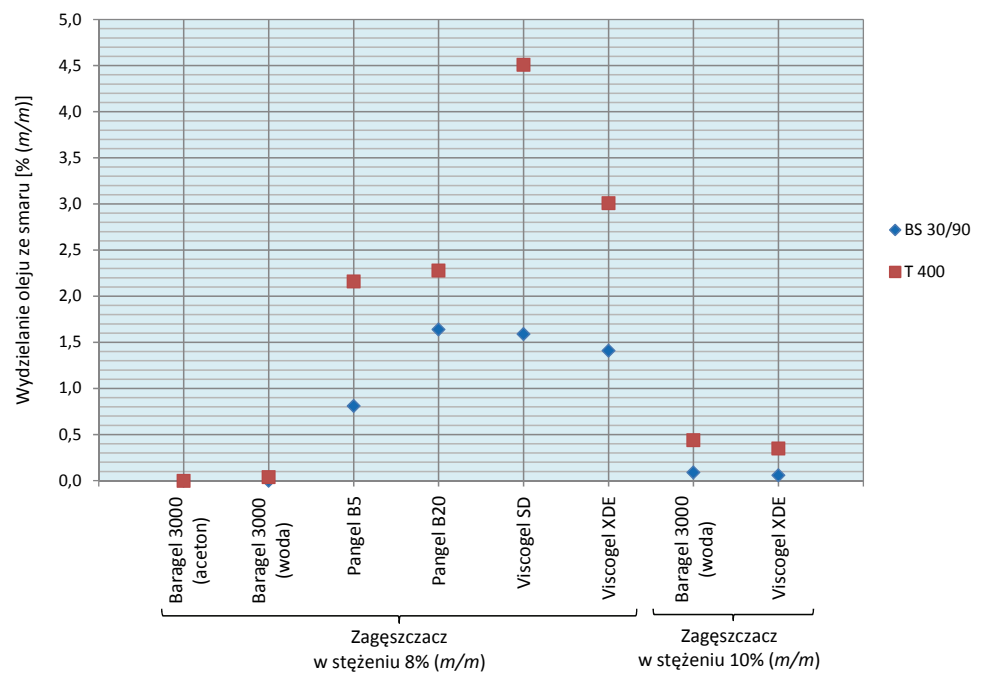

Rys. 4. Wpływ zagęszczacza na skłonność smaru do wydzielania oleju dla wytworzonych próbek smarów bentonitowych

leżności pomiędzy stężeniem zagęszczacza a ilością wydzielonego oleju.

\section{Wnioski}

Na podstawie wyników przeprowadzonych badań stwierdzono, że oba rodzaje wytypowanych olejów bazowych posiadały dobrą podatność na zagęszczanie. Lepszą podatność na zagęszczanie, a co za tym idzie wyższą klasę kon- systencji (o 1 lub nawet 2) uzyskano dla smarów bentonitowych wyprodukowanych z udziałem oleju o charakterze parafinowym. Najskuteczniejszym zagęszczaczem okazał się Baragel 3000. 
Badania z wykorzystaniem aparatu roll-test potwierdziły złą stabilność mechaniczną smarów bentonitowych, bez względu na rodzaj oleju bazowego czy zastosowanego zagęszczacza. Zaobserwowano, że smary wytworzone na bazie parafinowej charakteryzowały się gorszą stabilnością mechaniczną niż analogiczne smary wyprodukowane na bazie naftenowej. Niska stabilność mechaniczna nie dyskwalifikuje jednak smaru do stosowania w łożysku. Przykładami smarów bentonitowych ze słabą wartością stabilności deklarowanej przez producenta mogą być np. Bentomos 23 Lotos (stabilność wynosi 180\%) oraz Bentor 2 Orlen Oil (stabilność - 172\%) [10, 14].

Wszystkie wytworzone próbki smarów charakteryzowały się niewielką skłonnością do wydzielania oleju w wysokiej temperaturze, poniżej $5 \%(\mathrm{~m} / \mathrm{m})$. Potwierdza to dużą odporność smarów bentonitowych na działanie wysokich temperatur. Lepszą trwałością struktury charakteryzowały się smary powstałe na bazie oleju o charakterze parafinowym, natomiast spośród różnych zagęszczaczy - te zawierające w składzie Baragel 3000.

\section{Prosimy cytować jako: Nafta-Gaz 2017, nr 9, s. 707-414, DOI: 10.18668/NG.2017.09.11}

Artykuł nadesłano do Redakcji 20.02.2017 r. Zatwierdzono do druku 26.05.2017 r.

Artykuł powstał w ramach realizacji pracy inżynierskiej pt.: Badanie przydatności olejów bazowych o różnym charakterze do otrzymywania smarów bentonitowych - powstałej pod kierunkiem dr. inż. Mieczysława Chmury, na Wydziale Inżynierii i Technologii Chemicznej Politechniki Krakowskiej, Kraków, styczeń 2016 r.

\section{Literatura}

[1] Bentone, Baragel, Nykon. Rheological Additives. Organoclay Thickeners for the Lubrication Industry; www.monsonco.com/ wp-content/uploads/2015/02/Elementis-Grease-Handbook.pdf (dostęp: 06.01.2016).

[2] Czarny R.: Smary plastyczne. Wydawnictwa Naukowo-Techniczne, Warszawa 2004.

[3] Dresel W.H., Heckler R.P.: Some Aspects of Tomorrow's Greases. NLGI Spokesman, kwiecień 1994, s. 17-24.

[4] Grease Production Survey Report 2008-2011. NLGI.

[5] Kongres producentów smarów w Paryżu; www.wnp.pl/artykuly/kongres-producentow-smarow-w-paryzu,-7129.html (dostęp: 12.04.2016).

[6] Naphthenic specialty oils for Greases; www.nynas.com (dostęp: 06.01.2016).

[7] Olej bazowy BS 30/90 - specyfikacja techniczna; www.lotosoil.pl/pl/home/produkty/oleje-bazowe,2,400,show, 11958 (dostęp: 19.01.2016).

[8] Olej bazowy T 400 - specyfikacja techniczna; www.nyport.nynas.com/Apps/1112.nsf/wnsds/SE EN T 400/\$File/T 400 SE EN_SSD.pdf (dostęp: 05.12.2015).

[9] Przemysłowe Środki Smarne - Poradnik; www.total.com.pl/pro/ B2B-produkty-dla-przemyslu/li-materialy-informacyjne/li-poradnik.html (dostęp: 12.04.2017).

[10] Smar Bentomos 23 firmy Lotos - specyfikacja techniczna; http:/ www.lotos.pl/321/p,142,c,111/111/smar_bentomos_23 (dostęp: 12.01.2016).

[11] Smar bentonitowy Benterm 2 - karta informacyjna; www.naftochem.pl/benterm-2/ (dostęp: 12.01.2016).

[12] Smar bentonitowy Bentor 2 - Lotos Oil - karta informacyjna; www.lotos.pl/pobierz plik/40705 (dostep: 12.01.2016).

[13] Smar bentonitowy Bentor 2 - Orlen Oil - karta informacyjna; www.orlenoil.p1/PL/NaszaOferta/Produkty/Strony/BENTOR_2. aspx (dostęp: 06.01.2016).

[14] Smar Bentor 2 firmy Orlen Oil - specyfikacja techniczna; http:// www.orlenoil.pl/PL/NaszaOferta/Produkty/Strony/produkt. aspx?produkt=BENTOR 2.aspx (dostepp: 06.01.2016).

[15] Zagęszczacz Baragel 3000 - specyfikacja techniczna; www. elementisspecialties.com/esweb/webproducts.nsf/allbydocid/9D58CFBCABC36A838525773600517516/\$FILE/BARAGEL\%203000\%20MWF\%20DS\%20945\%205-2014.pdf (dostęp: 06.01.2016).
[16] Zagęszczacz Pangel B20 - karta informacyjna; www.tolsa.com aditivos/wp-content/uploads/sites/5/PANGEL-B20-EN-201409. pdf (dostęp: 06.01.2016).

[17] Zagęszczacz Pangel B5 - karta informacyjna; www.tolsa.com/ aditivos/wp-content/uploads/sites/5/PANGEL-B5-EN-201409. pdf (dostęp: 06.01.2016).

[18] Zagęszczacz Pangel OM4 - karta informacyjna; www.tolsa.com/ aditivos/wp-content/uploads/sites/5/PANGEL-OM4-EN-201409. pdf (dostęp: 06.01.2016).

[19] Zagęszczacz Pangel OMD1 - karta informacyjna; www.tolsa.com/aditivos/wp-content/uploads/sites/5/PANGEL-OMD1EN-201409.pdf (dostęp: 06.01.2016).

[20] Zagęszczacz Viscogel S4 - karta informacyjna; www.laviosa. com/wp-content/uploads/2015/06/LAVIOSA Coatings Viscogel-S4_TDS_ENG-rev-1.pdf (dostęp: 06.01.2016).

[21] Zagęszczacz Viscogel SD - karta informacyjna; www.laviosa. com/wp-content/uploads/2015/06/LAVIOSA_-Coating_Viscogel-SD-_TDS-_ENG-rev-1.pdf (dostęp: 06.01.2016).

[22] Zageszzczacz Viscogel XDE - karta informacyjna; www.laviosa.com/wp-content/uploads/2015/02/LAVIOSA_Coatings_Viscogel-XDE_TDS_ENG.pdf (dostęp: 06.01.2016).

\section{Akty prawne i normatywne}

[23] PN-C-04095:1985 Podziat smarów plastycznych na klasy wedtug konsystencji.

[24] PN-C-04144:1962 Oznaczanie stabilności mechanicznej smarów statych.

[25] PN-ISO 2137:2011 Oznaczanie stożkiem penetracji smarów plastycznych i petrolatum.

[26] PN-V-04047:2002 Badanie wydzielania oleju ze smaru w wysokich temperaturach.

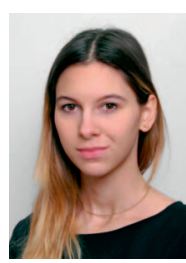

Inż. Patrycja STACHURSKA

Studentka studiów magisterskich kierunku Technologia Chemiczna na Wydziale Inżynierii i Technologii Chemicznej Politechniki Krakowskiej, specjalności Kataliza Przemysłowa.

E-mail: patrycja.stachurska@gmail.com 